\title{
There is No Alternative! Student Perceptions of Learning in a Second Language in Lebanon
}

\author{
Mike Orr \\ University of Edinburgh \\ Correspondence concerning this article should be addressed to Mike Orr, Moray House School of \\ Education, University of Edinburgh, Scotland, EH8 8AQ.E-mail: mike.orr@ed.ac.uk \\ Samer Annous \\ University of Balamand

\begin{abstract}
Correspondence concerning this article should be addressed to Samer Annous, Faculty of Arts and Social Sciences, University of Balamand, Balamand Al-Kurah P.O. box 100 Tripoli, Lebanon.
\end{abstract} \\ E-mail: samer.annous@balamand.edu.lb
}

\begin{abstract}
Since 1997, children in Lebanese state schools are taught most of the curriculum in English or French. The children's first language, Arabic, may be used even less in private schools, which educate $70 \%$ of children. In many countries, mother tongue education is seen as a right but in Lebanon it is taken for granted that children are taught in English or French. Written opinions were collected from seventy-five university students who were asked about the language in education policy. The results of a thematic analysis were discussed with a focus group of eight students. Findings point to a widespread acceptance of the policy, partly based on an underlying belief in the unsuitability of Arabic for the 21st century and a perception that the Lebanese are culturally predisposed to learn languages. Using the concept of linguistic imperialism, we discuss these results with reference to French colonialism and the global spread of English medium instruction. We also use a critical definition of ideology to discuss how a discourse in favour of the language in education policy, which actually favours the interests of the Lebanese elite, has been internalised by the students who see emigration as their only future.
\end{abstract}

Keywords: language policy, linguistic imperialism, ideology, Lebanese state school, mother tongue education, French colonialism

\section{There is No Alternative! Student Perceptions of Learning in a Second Language in Lebanon}

The right to be educated in one's own language has been recognised in several international agreements (UNESCO, n.d.) as a result of campaigns for regional and minority language rights. In Europe, for example, mother tongue education is now recognised as a legal right (Council of Europe, n.d) and in much of the postcolonial world governments have encountered similar pressures to legislate on language policy, albeit in ways specific to each country. In some, it was recognised that "every child should have the right to become literate in his or her mother tongue" (Wiley, 2013, p. 61). Thus, Malaysia legislated in 1970 for instruction in at least three languages (Abdullah \& Heng, 2003) to provide for mother tongue education for a larger proportion of its citizens. On the other hand, Morocco ignored the first language of its Berber population until the early years of the 21st century (Bentahila, 1983; Ennaji, 2005).

\section{The Rise of English as the Medium of Instruction}

It is interesting to note that the awareness of the importance of learning in a pupil's mother tongue seems to be countered by an increase in popularity for immersion, or "submersion" (Piller, 2016, p. 107), English medium education in primary and secondary schools, even in countries where English does not play a significant part in life outside the classroom and where other colonial languages still retain some influence (Dearden, 2014). One might claim that such a context, the "expanding circle" in Kachru's (1997) 
terms, is no longer easy to find on account of the global spread of English use via the Internet. However, despite the fact that English may be a part of an increasing number of people's regular lives through navigating online, such use of English is arguably more akin to a form of computer literacy than it is to the sort of communicative language ability (Bachman \& Palmer, 1996) that language teachers are used to discussing. Moreover, even accepting that many young people in these countries engage in some kind of Internet-based negotiation/exchange of meaning, it is useful to distinguish between basic communication skills and the cognitive academic language proficiency necessary for success at school (Cummins, 2008). It is certainly still worth inquiring about the reasons for teaching core curriculum subjects in a language that is not dominant in key domains in the pupil's society.

The use of English as a medium of instruction (EMI) in universities is also spreading across the world and is now a topic of increasing research and comment (Altbach, 2004; Belhiah \& Elhami, 2015; Coleman, 2006; Dearden \& Akincioglu, 2016; Green, Wang, Cochrane \& Paun, 2012; Kirkpatrick, 2017). These authors link the shift to EMI to the emergence of English as the lingua franca of international business and diplomacy, as well as the internationalisation of higher education as universities try to attract fee paying students from other countries. Coleman also identifies a degree of pragmatism in the shift to EMI. Referring to "the Microsoft effect" (p. 4), he suggests that once English medium instruction in universities has become dominant, it is no longer practical to choose another language.

Decisions about language of instruction, and especially about adopting a new language as a medium of instruction, are influenced by how power is distributed in any one context (Wright, 2007). Wright explains that to "... relinquish the use of one's own language to make space for the language of another group is almost always indicative of a shift in power relations" (p. 124). Power and, by implication, inequalities of power are also the keys that Tollefson (2013) identifies for investigating any aspect of language use in education.

Teaching in English, the teaching of English and relations of power in the world have been the topic of a major polemic in the last twenty-five years. Phillipson (1992; 2009; 2017) argues that there is a deliberate policy on the part of the UK and the USA to further their economic interests by promoting the expansion of English, a policy that he describes as "linguistic imperialism". Phillipson's work has been severely criticised, among other reasons, for seeing conspiracy, instead of benevolence, at work in aid and development projects (Davies, 1996). However, his ideas have had an important influence on the way we think about English and English Language Teaching (ELT) (e.g., Edge, 2003; 2006). In a response to Davies, he argues that, "Linguistic imperialism takes place within an overarching structure of North/ South relations, where language interlocks with other dimensions, cultural (particularly education, science and the media), economic and political" (1997, p. 240). Said (1993), whose contemporaneous work on cultural imperialism, was better received, makes a similar claim: "In our time, direct colonialism has largely ended; imperialism, as we shall see, lingers where it has always been, in a kind of general cultural sphere as well as in specific political, ideological, economic and social practices" (p. 9).

While the term imperialism was perhaps unpopular in the early 1990s, when many found reasons for optimism as the Soviet Union broke up, the concept has regained currency. Hardt and Negri (2001) consider empire an appropriate term to describe the status of the global capitalism in the 21st century and, within the admittedly more restricted field of ELT, well-known authors were invited to contribute to a volume about teaching English in an age of empire (Edge, 2006).

In Phillipson's (2008; 2017) analyses of the workings of linguistic imperialism, he makes use of an idea from Harvey (2005), accumulation through dispossession. This is originally an idea to explain late capitalism's pursuit of profit through the commodification of anything left in common ownership such as public health and education services. Phillipson uses the concept to comment on Grin's (2004) analysis of the way some countries find their language is of questionable value and the advantage the USA derives from the global spread of English. He looks into the savings to the USA of not having to invest in translation and foreign language teaching to support its international trade as one example. In the discussion, Phillipson is also sensitive to the loss of cultural capital (Bourdieu, 1992). An example of this would be the case of Egyptian primary school children being taught English in order to become computer literate at the expense of learning to be literate in Arabic (Warschauer, 2003). Elsewhere, Pathak's (2011) account of donning flak jackets to teach English to the new Iraqi army (after the established army was disbanded) may also be seen to provide some support for Phillipson's (2009) claims about a continuing linguistic imperialism aimed at increasing profits for national and multinational businesses based in the West by reaching into new territories and social domains.

Phillipson (1997) more generally considers analysis of linguistic imperialism to be part of linguicism studies, which scrutinize, "how language contributes to unequal access to societal power and how linguistic hierarchies operate and are legitimated" (p. 239). This is not a new idea but it is relevant to the spread of 
EMI. Block (2015) gives examples of unequal access to societal power from several parts of the world and concludes that, "we are beginning to see a correlation between class position and individuals' access to and success in English language learning" (p. 11). This should concern us as we see basic education increasingly delivered through English. Of course, EMI in schools is not necessarily problematic, but an approach to EMI that maximises the use of English as an end in itself would need to be criticised from a social justice perspective.

What we can take from the authors commented on thus far is a clear understanding that the teaching of English in the world is not a neutral endeavour. Kumaravadivelu (2006) points out that TESOL professionals operate at the intersection of globalisation, empire and English and, "knowingly or unknowingly, play a role in the service of global corporations as well as imperial powers" (p. 1).

The idea of language use serving the interests of people in power points to the relevance of ideology. Phillipson (1992) would argue that that many of the beliefs supporting the spread of EMI are mistaken and are, in fact, "fallacies" (p. 194). In a more recent publication, he includes such beliefs in what he calls "the myths of global English" (2017, p. 315). These beliefs, which he argues are still dominant and underlie the acceptance of EMI, include the idea that use of a single language in class is better than bilingual instruction, that native-speaker teachers are to be preferred and that as early a start as possible is important for learning a second language. Looking into how fallacious beliefs develop is one focus of ideology studies.

In the literature on second language teaching, the term ideology is used inconsistently (Orr, 2014). At times, it has negative connotations, much like the word dogma, and, at others, as in the literature on language policy, it is viewed from neutral and/or critical perspectives (Johnson, 2013). A useful review of the term is Thompson (1990) who argues for a definition that sees ideology as basically "meaning in the service of power" (p. 23) or the use of language "to sustain relations of domination" (p. 56). Thompson's definition allows for a discourse to be more or less ideological inasmuch as it serves to make an unequal power relation acceptable and to appear to the dominated as something natural, neutral and eternal (or at least longstanding). The processes by which this happens are referred to by Thompson as legitimation and reification. The first confers authority on an idea while the second makes the idea appear to be something not created by people and thus beyond our control. Although Thompson's work on ideology is mostly used in media and cultural studies, it has also been used by education researchers working in different areas such as critical literacy (Janks, 2014); ELT textbook evaluation (Fitzgibbon, 2013); inclusive education (Slee, 2001); university teaching of accountancy (Ferguson, Collison, Power \& Stevenson, 2009) and international law (Marks, 2001).

Not all authors writing about the emergence of English as a lingua franca view it in such a critical manner. They are generally more descriptive in their comments or write about how the teaching profession can adjust to the new reality (Dearden \& Akincioglu, 2016; Galloway \& Rose, 2015; Ostler, 2010). There may be a sense that if much of the world of work requires proficiency in English then schools and universities should help pupils and students by teaching in English. However, this seems a poor rationale for denying children the right to an education in core subjects in the language that they speak at home with their parents or other care-givers. A sign that the debate is to get more attention was the launch of a new research centre for EMI at the University of Oxford in March 2014 (EMI Oxford, n.d.), although the representation of EMI as an "unstoppable train" (Macaro, 2015, p. 7) might be taken to mean that, not only do we have no choice in the matter but that there may be undesirable consequences.

\section{Language in Lebanon}

The last one hundred and fifty years in Lebanon have seen Turkish, Arabic, French and English compete for space in education. Other languages spoken in the country include Kurdish and Armenian and more recently it has become very common to hear the languages of Sri Lankan, Ethiopian and Philippine migrantworkersinaddition to PidginArabic(something Bizri (2010) calls "pidgin madam" and which developed because of the contact between Sri Lankan domestic workers and their Lebanese employers). Moreover, many Lebanese describe themselves as "English educated" or "French educated" - a reference to the fact that much of the school curriculum is delivered in one of these two languages.

The relationship between identity and language in Lebanon is the topic of continuing research and discussion (e.g., Al Batal, 2002; Diab, 2009; Esseili, 2014; Joseph, 2004; Marcus, 2016). While the first independent government in 1943 proclaimed the country as one with an Arab face, or character, the implication was that the body might be something else. Indeed, this is what is contested, with some arguing for a historical Arab identity and others for alternative histories, albeit in an Arab milieu. Based on the 1943 Constitution, power in Lebanon is allocated to the leaders of religious sects. A struggle to change the distribution of power in 1975 led to fifteen years of civil war. Early on in the war there may, in fact, have 
been aspirations to end the sectarian system but the forces dedicated to maintaining it, albeit reshaped, were too powerful (Traboulsi, 2007). The civil war ended in 1990 and a long process of rebuilding the country began. Education reform was part of the process and this included decisions about the medium of instruction.

\section{Schooling in Lebanon}

Organized schooling for all children in Lebanon dates from the French mandate (1920-1943) when the language of instruction was Arabic and French. This became mainly Arabic post independence - at least officially. Notwithstanding the official position on Arabic, the widespread use of French continued despite criticism from nationalist intellectuals. Amil (1968/2007), for example, argued that the use of French discriminated against poor Lebanese children and that the education policy served to reproduce the elite class of Lebanese who had collaborated with the old French colonial power to maintain their privilege at the expense of the development of society. In addition to French, English began to establish a place for itself as a medium of instruction in the national school system. Diab (2006) sees this as a response to the growing importance of the USA in the region (US dollars are one half of the dual currency in Lebanon). When the civil war ended in 1990, attempts to establish a common identity and purpose included a new policy on language in education. In the case of Lebanon, Arabic was "made central to post-civil war unity" (Zakharia, 2009, p. 215) and the 1997 national curriculum made it the common language for all Lebanese school students no matter which foreign language might also be used. However, as Zakharia shows, Arabic is undermined by a complex of local and international factors, and, as a consequence, "devalued vis-à-vis other school languages" (p. 229). The current situation is that, officially, lessons are in French or English for science and mathematics and other subjects are given in Arabic. Unofficially, the language in education policy is implemented differently across the country, due to the existence of "a centralized government-mandated national curriculum delivered through highly decentralized schooling practices" (Zakharia, 2010, p. 158). Zakharia points to the growing network of private schools which educate around $70 \%$ of children (MEHE, 2014) in Lebanon. Many of these are subsidised by the state and run by foundations linked to the religious sects whose leaders form the government. These private schools "are linked to national networks that intercede in the implementation of top-down government school policies and create policies of their own" (Zakharia, 2010, p. 158). This means that Arabic may be used even less than officially intended.

Lebanon is thus an interesting case study, as a number of factors interact with each other and relate to decisions about the use of Arabic, French and English in education. There is the attempt to use the language of instruction to assist in developing a national identity while maintaining an economic and cultural and political relationship with the old colonial power of France. This relationship is said to be more important for Christian (particularly Maronite) Lebanese (Joseph, 2004; Suleiman, 2006). There is also the economic and political relation with the new imperial power (USA). The USA takes great interest in Lebanon because of its position in the region and its border with Israel. And, finally, there is the general trend towards EMI already discussed, which sees French losing ground in Lebanon (Diab, 2009; Esseili, 2014; Kadi, 2016; Suleiman, 2006). In other countries in the region, there seems to be concern about the presence of a second language as the medium of instruction in education and the consequences for Arabic (e.g. Bell, 2015; Findlow, 2006; Lindsey, 2015; Raddawi \& Meslem, 2015; Solloway, 2017). However, in Lebanon, there is much less concern, perhaps because of an unquestioned assumption that the country is multilingual (Bahous, Bacha \& Nabhani, 2011; Marcus 2016). There are occasional attempts to raise the issue (Shawish, 2010) but the literature does not include the kind of studies that have emerged from other Arabic speaking countries. Perhaps one obstacle is the refusal by some to even acknowledge the Lebanese dialect as Arabic (Salameh, 2010).

Another reason Lebanon is interesting to study is the presence of Palestinian children in Lebanon who attend schools run by the United Nations inside the refugee camps (around 400,000 people live in camps established more than 60 years ago when they had to leave their homes in historic Palestine). The Lebanese curriculum is followed, as is the language of instruction policy, and teachers struggle with the same problems as their colleagues outside the camps, exacerbated by the pressures of refugee life. Furthermore, since 2012, thousands of Syrian refugee children trying to access schooling in Lebanon have experienced the challenge of being taught in a second language.

Lebanon has very high school enrollment rates compared to other countries in the region, but the dropout rate is high and the repetition rate is the highest in the region. Problems with second languages are highlighted as one of the main challenges for students (UNICEF, 2012, p. 8), and, indeed, for teachers (MEHE, 2014, p. 15). Docherty, Barakat, Kniveton, Mikati and Khalifa (2017) claim that of 4000 Lebanese school teachers tested, 95\% needed to improve their English to reach recommended levels. The UNICEF report into the plight of Syrian refugees in Lebanon 
serves to highlight the problems facing poor Lebanese children whose classrooms they share in many of the rural areas. Thus, if "the language barrier stands as a towering impediment to the right to education" (UNICEF, 2012, p. 14) for the refugees, it is hardly less so for many poorer Lebanese children whose families have only basic proficiency in English or French, if at all. Ironically, both the refugees and their Lebanese host communities share the same mother tongue. In Syria, this is the language of instruction, but in Lebanon, it is replaced to a great extent by a foreign language.

\section{Research Focus}

Our interest in the medium of instruction in Lebanon developed over a number of years spent working with teachers of English and the increasing number of teachers of other subjects who teach in English. It can be argued that a policy whereby more than half the mandatory curriculum is taught in a language other than the pupils' mother tongue must rest on the assumption that the pupils have enough ability in English or French to be able to learn the curriculum to a satisfactory standard, or that they will develop this ability in the course of their studies with no disadvantage occurring. It seems reasonable to question these assumptions given that most Lebanese have Arabic as their mother tongue and pupils outside the capital do not live in communities where either English or French are widely spoken in everyday life. Most university programmes are in English or French but the universities have to run pre-sessional language programmes for many of their students. Shaaban (2005; 2013) comments on Lebanese school leavers' generally inadequate level of second language proficiency for university study. We decided to investigate this issue from the perspective of our students. The following general research question was formulated: What do Lebanese university students think about the second language medium of instruction policy and what reasons do they give for their opinions?

\section{Methods}

\section{Research Context}

The research was carried out in a private university in the north of Lebanon. The medium of instruction is officially English with a few courses delivered in French. Courses for a degree in Arabic language and literature are taught in Arabic. The university provides English language support for students in the form of a pre-sessional "Foundation" year, which consists of courses in English for Academic Purposes (EAP). There are also a number of courses for academic writing development that can be taken during a student's major.

\section{Participants}

The participants in this study came from classes taught by the researchers. A total of seventy-five students (from around one hundred) agreed to take part. Twenty-nine students were female and forty-six male. Fifty of the students were drawn from the Foundation year cohort and another twenty-five students were undergraduates drawn from an option module called Language, Society and Culture. A significant majority of the students had chosen to study for science and technology related degrees. The university is relatively expensive, although scholarships are available, so the students ,arguably, may be considered to come from middle-class backgrounds. The students were not asked about their religion. This was in contrast to Diab (2009) who also asked Lebanese students in an English medium university about their attitudes to the use of Arabic, English and French. In our case, we were interested to learn about ideas common to all our students, regardless of religious identity. The students were informed about the project and were asked in English and Arabic for permission to use their data and given the option to withdraw at any time.

\section{Data Collection}

As part of their course work, all these students were asked to write about the language in education policy in Lebanon. This consisted of an essay in which they were asked to give and explain their opinion. The course work was formative and did not count towards any formal assessment. The participants are those students who gave permission for their texts to be used as data in this research. The students were also invited to be part of a focus group to discuss the initial analysis. Subsequently, eight students attended a focus group session of one hour. The discussion was conducted in Arabic and English, recorded and transcribed.

\section{Data Analysis}

Both researchers view language (in) education from a critical and social justice perspective (Hawkins, 2011). As such, we are interested in understanding the way people with less societal power lose out as a consequence of the way different aspects of education are designed and practised. It was inevitable that such a critical perspective would influence the way we selected units of data for discussion. Recognising this reality, we tried to ensure that all the data was 
analysed and that we did not begin by looking for evidence to support our own expectations. Therefore, an inductive approach similar to that described by Robson (2011, pp. 474-488) was taken to analysing the data. We read the students' work and identified every segment of text that constituted a unit of meaning. Each one was then assigned to a category suggested by the segment itself. Each segment was compared with those segments already placed in categories and, if necessary, a new category was created. Initially, some segments were assigned to more than one category. There is, of course, an important degree of subjectivity in deciding what counts as a unit of meaning. For example, we decided that the following piece of text constituted one unit of meaning rather than two: "Lebanese people are special and different from all Arabic people" (student 1). We put this segment in a category called "Lebanese uniqueness". At first, we assigned this segment to another category as well ("Lebanon is different from other Arab countries") but in the end this second category was seen to be less clear-cut than the first and the two were merged.

Eventually, all segments were assigned a single category through discussion between the researchers. The categories were then collected into themes that made discussion of the data more manageable and that reflected our interest in developing a critical understanding of the students' perceptions of the language in education policy. The focus group discussion was based on presenting the themes to the participants and asking them for their reactions. The ease with which they engaged with the discussion and the fact that they did not want to change the topics supported our sense of having identified the key aspects in the data.

\section{Results}

The results of the data analysis show that we sorted the students' comments into several categories, ten of which are relevant to the issue of their perceptions of the language in education policy in Lebanese schools. We were able to see three broad themes, each of which is made up of several categories of recurring ideas. These themes are explained below and illustrative quotes are provided.

Theme 1: Learning for the Modern World (Science, Technology, Business and the Media) Cannot be Done in Arabic

The students repeatedly refer to English and French as the vehicles for scientific knowledge while Arabic is referred to as a hindrance to learning science. This theme links the following categories:
Science comes from the West (and by extension, scientists are not Arabs). "The use of English is a must in some fields because there are no achievements of experiences done in Arabic" (student 34).

Key concepts in science and technology cannot be understood in Arabic (translation is not possible and by extension, "native" English speaking teachers are desirable). "If Arabic was chosen as the language in teaching this could be an educational disaster... look at words like cylinder, we use the same word in Arabic because to translate it, no one will understand what I am referring to" (student 32).

Arabic is not a world language. "...the native language of a country must not necessarily be used in the subjects of its education system especially if this language is universally weak and difficult to learn" (student 50).

\section{Theme 2: Success in Life Involves Emigration}

This theme is related to the previous idea about modern life being lived in international languages. This theme links the following categories:

Job prospects in Lebanon are limited (and so emigration is inevitable and the poor people are the ones who only speak Arabic). "The ability to speak languages gives us the opportunity to work in a country that pays higher wages" (student 49). "In other countries, the poor schools teach in Arabic ...yeah the poor, the school that belong to the poor community" (student 75).

Postgraduate studies are better if followed in the parts of the world that produce modern ideas (and, by extension, the non-use of Arabic helps prepare for study abroad). "English support students studying at universities all over the world and it facilitates the opportunity for students to find jobs in the evolving market" (student 37).

The role of school is to prepare students for emigration. "We can know the success of the Lebanese people from the school system, the system obligate the student to study three languages. In addition, most Lebanese travel and work outside so they need to learn languages" (student 26).

Theme 3: The Lebanese are Able to Benefit from the Language in Education Policy because of a Unique Pragmatism, a Cultural Predisposition that Involves a Desire to Learn and Openness to the World.

The common thread here is the idea that Lebanon is a crossroads where different powers meet and through which different peoples pass, some of them settling. This is related to the idea of Lebanon having a unique geography that leaves it squeezed between the sea and high mountains, beyond which lies the desert. 
References to the unique geography, differentiated from everything to the east, give way to references to a unique culture, also expressed as different to everything to the east and, particularly, to other Arab countries. This theme links the following categories:

Lebanon is unique. "Lebanese people are special and different from all Arabic people" (student 1).

Lebanon is a physical and cultural crossroads. "Lebanon is small and located between three continents. The location attributes to Lebanon the quality of linking culture... the number one country in the Middle East when it comes to communication and learning process" (student 2).

The Lebanese are open to new ideas and learning (and by extension they are good language learners). "They want to be opened on all the world. One important way to follow the world's improvements is that they learn other languages to understand everything" (student 7). "We find people more cultivated and educated, they can speak more than a language by the age of ten" (student 38). "Lebanese are known for their ability to learn lots of languages" (student 28).

The Lebanese ability in languages comes from their pragmatic outlook. "Despite the wars and what they have been through they learned to adapt to all situations and live with what they have" (student 21). "In other countries such as Syria, in most schools, Arabic is the main language that is used for most subjects. That is why they are known through Arabic countries as good Arabic speakers, as average citizens, public speakers and politicians. Lebanon on the other hand has a reputation of "having the survival skills wherever you throw them'” (student 40).

\section{Discussion}

The general research question that we started with was, "What do Lebanese university students think about the L2 medium of instruction policy and what reasons do they give for their opinions?" The answer in the case of our participants is that they generally approve of the policy and that their reasons are largely pragmatic, based on recognition of the utility of English in the global world of work. Running through the data is the sense that Arabic is not a language of power and an almost unanimous belief that not using in the mother tongue in school is a positive feature of the Lebanese education system. This finding is consistent with the results reported in Diab (2009) and Esseili (2011). Much of our participants' reasoning also seems to be based on a sort of common sense about the inadequacy of Arabic for dealing with the concepts of the modern world.
In an effort to follow the trend towards critical perspectives in language policy related studies (Johnson, 2013) we will now discuss the findings using Phillipson's (1992; 2009; 2017) ideas about linguistic imperialism and Thompson's (1990) ideas about ideology. In doing so, we are conscious of Johnson's warning that "focusing exclusively on the subjugating power of policy" can make it appear "monolithic" (p. 43). However, we hope to avoid this by considering the multiple influences of past colonial history, the reality of globalisation today, the nature of political power in Lebanon and a dominant narrative about Lebanese identity.

\section{Linguistic Imperialism}

We can see awareness of the idea of a global hierarchy in the students' sense of having to accept the struggle to learn in a second language in order to be as good as the source of new ideas, i.e. the West. They have accepted that their lot is to run fast so that they can keep pace. The efforts of western cultural organisations to improve French and English language teaching are also based on this belief. Lin and Luke (2006) put it like this, "The core ontogenic assumption of colonialism and, indeed, of the new forms of economic and cultural empire is that the 'Other' is playing a linear game of individual, technological and cultural 'catch up'" (p. 69). Our students' perception of Arabic, in line with Zakharia (2009), as a language of the home, associated with history and religion, goes hand in hand with their sense of needing to work in the more valuable languages of the powerful in order to try and catch up. Lin and Luke would not be surprised that one of the students made the comment that, "Arabic can't cope with the modern world as fast as English" (student 6). Thus, instead of developing their thinking and expression in Arabic and English, our students accept that their intellectual progress will be formed solely through English. This is the integrated process of linguistic capital accumulation and dispossession referred to by Phillipson (2017).

It is interesting to contrast the students' perceptions of Arabic with perceptions of another language being replaced by a second language as the medium of instruction, Chinese. While Arabic appears to be considered a language of limited value, Kirkpatrick (2014, p. 5) takes it for granted that Chinese universities recognize that Chinese is a "vibrant and important language of communication and scholarship" despite being replaced by English on some programmes. This difference is arguably due to the relatively strong position of China in the global balance of power.

We have seen that those students in Lebanon who succeed in graduating from the school system to reach 
university consider emigration as the necessary next step. When they do so, they contribute directly to the process of accumulation through dispossession (Grin, 2004 ), in this case by a poor country adding to the wealth of richer countries by exporting its educated youth. Moreover, it is these students who can aspire to better incomes. In this sense, the language in education policy helps maintain unequal access to societal power.

\section{Ideology}

The perception that the imposition of an L2 medium of instruction is a normal and acceptable state of affairs can be considered in relation to the processes of "reification" and "legitimation". These are two of the key ideas that underpin Thompson's (1990) discussion of ideology in terms of how language is used to create "meaning in the service of power" (p. 56). In the case of this research project, we have considered language in more ways than one. Firstly, there is the language of instruction, English, French or Arabic, and secondly, there is the language used by our participants to express themselves. Thirdly, there are also the discourses about Lebanon to which the students make reference.

Reification. This is a major process whereby a temporary, historical state of affairs is portrayed as if it is permanent and natural. Thus, the social world is observed by people in the same way they might observe a mountain; they do not see it as something they shape and can change. All of the students made comments suggesting that it was common sense to study in a second language. In the following example one of the students explains that, "Most of the schools teach the scientific courses in French or English. It's important for students to know how to speak these languages to make education easier to follow" (student 7). Thus, second language medium instruction is necessary because it will help the pupils understand lessons given in a second language.

Legitimation. This is another major process in which we see the way ideas are universalised, rationalised and narrativised. Universalisation is the process by which the exercise of power is presented as rooted in mutual interest. In the next example, we can see how a student sees the decision to use a second language as the medium of instruction as a positive decision taken in the best interests of everyone: "In Lebanese schools opportunities will be open and choices infinite with French and English rather than Arabic. It's true that students are Lebanese but they will be recognised according to their education and knowledge and not their culture. I prefer to be open to the world and not limited to the Arab world only." (student 33).
Rationalisation is the process by which events are seen as logical and alternatives as irrational. In the data, there are clear expressions of disbelief that schooling could be different, despite their own experience of seeing teachers at school and university use Arabic to discuss difficult concepts introduced in the second language: "Some majors cannot be taught in Arabic. In schools, these subjects are taught in English and French. To follow educational progress we must use the language of research.” (student 34); “...it is so difficult to study scientific subjects in Arabic... If you ask somebody in Lebanon why are you are learning this language he will answer by just saying it is simpler than the Arabic language and its complexity... there is no qualified teachers who teach scientific subjects in Arabic" (student 49). It is ironic that the UN report (UNICEF, 2012) on the experiences of Syrian refugee children in Lebanese schools includes the story of a school where the teacher decided to use Arabic out of sympathy to the students and reported, "We give them sciences in French, so I suggested that we give it in Arabic, they did better than the Lebanese" (2012, p. 16).

Finally, narrativisation is the process by which practices are set in historical context and seen as worthy of respect. The ideological move of narrativisation is clearly evident in the way all students refer to the history of Lebanon in their explanations of why Lebanese students can cope with second language medium instruction. There are references to the Ottoman rulers, the French and the Americans. There is pragmatism here, recognising the reality of foreign powers and rationalising education policy decisions (in favour of the languages of these powers) as a logical consequence - for example, "Lots of people learned French language when the French army was in Lebanon" (student 5).

There is also another narrative at work, the idea of Lebanon as open to all cultures through its geographical position as a crossroads between east and west. This is the Lebanon that is the safe refuge for people escaping oppression. It is also as the Lebanon of the Phoenician myth (Kaufman, 2014; Traboulsi, 1999) that is home to a society of sea traders who become entrepreneurs through skilful negotiation of their contacts with other peoples and because of a desire to learn. The following examples show this sense of history, geography and culture: "Variety of cultures that passed through left behind people that speak different languages, like Armenian" (student 3). "Lebanon is an open country that links Gulf countries to European countries" (student 27). "Lebanon geographically is located in a strategic position in the Middle East due to its sea ports in the Mediterranean sea... Lebanon merchants must learn any languages to communicate in foreign trading" (student 22). 
We have seen how our students are positive about the use of second languages at the expense of Arabic on the basis that they are better prepared for a life abroad. It may seem strange that a school system should be approved of because it prepares the country's children to leave but underlying this idea is the awareness that there is little work in Lebanon and what work exists is not well paid. We know from Yaacoub and Badre (2012) that $53 \%$ of graduates living in Lebanon are unemployed. (Shaheen (2016) adds corruption to the causes driving Lebanese youth to emigrate). The link between poverty and not knowing English and/ or French is made explicit by several students. The need to emigrate is rationalised on the basis of the situation in Lebanon, but the idea that the situation could be different is not considered. The economy and the effects of globalisation are effectively reified, reproducing the discourse of "there is no alternative" that is the slogan of neoliberalism (Holborrow, 2007). Emigration is also commented on as something which the Lebanese have been doing for a long time and the link to the story of previous generations makes it easier to accept the need to leave.

\section{How the Elite Benefit}

If the role of ideology is to sustain unequal power relations in society, then, in this case, we would argue that the elite in Lebanon benefit from the unquestioning use of second languages as a medium of instruction in education through the production of graduates who emigrate and whose remittances are extraordinarily important for the economy (Nader, 2014; Atalla \& Ezzeddine, 2017). The way this policy is perceived makes the Ministry of Education appear to be providing the key skills that every child needs despite the high repetition and drop out rates. Nader cites a report that shows the government benefits because over $60 \%$ of remittances from Lebanese working abroad goes on food expenditures as recipients working in Lebanon are poor and those without work have no welfare payments to rely on.

The reproduction of the narrative of the pragmatic, resourceful Lebanese (also seen in Diab's (2009) results) arguably places the responsibility for any lack of success at school on the individual who does not have the necessary desire to learn. It might also be seen to relieve the Ministry of Education of a responsibility to invest in the kind of professional development necessary if teachers are to work in a second language (or ideally multiple languages) because there is an assumption that, while it is a challenge, it is one the Lebanese are culturally equipped to deal with. There is also a benefit to the religious elites whose private schools attract parents aware of the lack of resources in the government schools.
Finally, the discourse around the use of English and French in education can be seen as part of those discourses that present Lebanese society as different from Arab societies, despite the "Arab face". The idea that Lebanon is qualitatively different benefits the religious elites, who have little interest in a strong central authority of the kind historically found elsewhere in the region (Traboulsi, 2007; Salamey, 2014; Salloukh, Barakat, Al-Habal, Khattab \& Mikaelian, 2015).

Our main area of interest is the teaching of English so this is where we will direct some final comments. It is encouraging that recent years have seen a critical focus on EMI developing (Barnard, 2015; Shohamy, 2013; Wilkinson, 2012), and Kirkpatrick (2014) argues that action can be taken to resist EMI in favour of a $\mathrm{bi} /$ multilingual model more appropriate for the $21^{\text {st }}$ century. While some may see EMI as an "unstoppable train” (Macaro, 2015, p. 7), Kirkpatrick's metaphor is that the "EMI horse has bolted" (2016), one that at least suggests regaining control is possible. In our opinion, discussions about EMI, for example on postgraduate programmes in ELT, without reference to social class, to the people who benefit and to those who are disadvantaged, are themselves ideological because they present EMI as a generally neutral or beneficial development. Unfortunately, social class is not a topic that is common in mainstream literature in ELT, in contrast to writing on education more generally (e.g. Bisseret, 1979; Wrigely and Smyth, 2013). Another reason to want a critical perspective is the questionable linking of EMI with modernising that belittles local knowledge and expertise. For example, Dearden, (2014), in her report for the British Council, writes that university degrees from Kazakhstan were previously not recognised in the developed world because of the country's Soviet background. Now, however, in Kazakhstan, there is the perception that, "EMI is not simply a new medium of instruction, but also a way to implement a pedagogy and curriculum which is more in line with established world standards of teaching and assessment" (p. 19). Even more recently, the Malaysian government has decided that all locally produced English language textbooks will be replaced by UK publications (Aris, 2017). This perception of the superiority of western ideas about language and teaching supports the use of linguistic imperialism and ideology as a framework for the analysis of EMI in many contexts. If discussion of EMI, or the adoption of any other second language as a medium of instruction, is not conducted critically, the main problems considered are technical ones (e.g. Vu and Burns, 2014), such as not having enough appropriately trained teachers. This assumption unfortunately elicits responses (e.g. Cambridge English, n.d.; Docherty, et al., 2017) that perpetuate 
the impression that solutions are to be found amongst foreign experts.

\section{Conclusion}

In this paperwe have considered university students' perceptions of the way that English and French are used in Lebanese schools. Our study is limited to participants at one English medium university and cannot claim to be representative although there are similarities with some of the conclusions of other researchers (Diab, 2009; Esseili, 2011; Zakharia, 2010).

We think that it is important that studies into the use of second languages as the medium of instruction, and the possible marginalising of the mother tongue in schools, take a critical perspective. We have tried to do this by using core concepts of linguistic imperialism and ideology. In Lebanon, French as a medium of instruction is a legacy of colonialism. Back in 1968, Amil (1968/2007) criticised the discriminatory effects of French as a language of instruction in core subjects, "Behind a heavy curtain of slogans about cultural openness, what is hidden is the fact that the majority of Lebanese pupils' needs are being ignored as a result of the way science and the Arabic language are treated in school." (p. 11). On the other hand, the widespread use of English is a relatively recent development and one that is linked to a globalisation that sees access to English correlate with social class (Block, 2015). The students in our study made several comments that clearly linked English proficiency with avoiding poverty.

We suggest that practitioners in Lebanon give more consideration to the value of a multilingual pedagogy that develops and makes use of their students' full range of language and literacy skills, including Arabic, in the teaching of all curriculum subjects. Future research could investigate the implementation of such a pedagogy in selected schools across the diversity of contexts existing in Lebanon. As mentioned earlier, the literature on language of instruction in Lebanon does not reflect the same concern for mother tongue education as seems to exist in other countries in the region. A research agenda that focused on multilingual classroom practices could take advantage of the perception in Lebanon that schooling needs to happen in more languages than just the mother tongue, and, at the same time, shift attention towards improving the school experiences of all the country's children.

\section{References}

Abdullah, A. N, \& Chang, S. H. (2003). Gaining linguistic capital through a bilingual language policy innovation. South Asia Language Review, $13(1,2), 100-117$.

Al Batal, M. (2002). Identity and language tension in Lebanon: The Arabic of local news at LBCI. In A. Rouchdy (Ed.), Language contact an language conflict in Arabic: Variations on a sociolinguistic theme (pp. 91-115). London, UK: Routledge.

Altbach, P. (2004). Globalisation and the university: Myths and realities in an unequal world. Tertiary Education and Management, 10(1), 3-25.

Amil, M. (1968/2007). Fi qadiyya at-tarbiyya wa assiyasiyya at-t3alimiya [On the issue of upbringing and education policy]. Beirut, Lebanon: Dar Alfarabi.

Aris, A. N. (2017). Imported English textbooks will boost students' proficiency'. Retrieved from http://www.freemalaysiatoday.com/category/ nation/2017/10/07/imported-english-textbookswill-boost-students-proficiency/

Atallah, S., \& Ezzaddine, N. (2017). Hariri is back but Lebanon's sovereignty remains hijacked. Retrieved from https://www.lcps lebanon.org/ featuredArticle.php?id=128

Bachman, L., \& Palmer, A. (1996). Language testing in practice. Oxford, UK: Oxford University Press.

Bahous, R., Bacha, N., \& Nabhani, M. (2011). Multilingual educational trends and practices in Lebanon: Acse study. International Review of Education, 57(5,6), 737-749. Retrieved from http:// www.jstor.org/stable/41480154.

Barnard, R. (2015). EMI in Asian universities. Modern English Teacher, 24(2), 9-11.

Belhiah, H., \& Elhami, M. (2015). English as a medium of instruction in the Gulf: When students and teachers speak. Language Policy, 14(3), 3-23.

Bell, J. (2015). Arabic language is losing value: Arab Youth surve. Retrieved from http://www. thenational.ae/uae/arabic-language-is-losingvalue-arab-youth-survey

Bentahila, A. (1983). Language attitudes among Arabic-French bilinguals in Morocco. Clevedon, UK: Multilingual Matters.

Bisseret, N. (1979). Education, class language and ideology. London, UK: Routledge \& Kegan Paul.

Bizri, F. (2010). Pidgin Madame: Une grammaire de la servitude. Paris, France: Geuthner.

Block, D. (2015). Social class in applied linguistics. Annual Review of Applied Linguistics, 35, 1-19.

Bourdieu, P. (1992). Language and symbolic power. Cambridge, UK: Polity.

Cambridge English. (n.d.). Retrieved from http://www. cambridgeenglish.org/images/272243-coursecertificate-in-emi-skills-overview.pdf

Coleman, J. (2006). English-medium teaching in 


\section{THERE IS NO ALTERNATIVE!}

European higher education. Language Teaching, 39(1), 1-14. Retrieved from org.ezproxy.is.ed. ac.uk/10.1017/S026144480600320X

Council of Europe. (n.d.). Retrieved from http:// www.coe.int/en/web/conventions/full-list/-/ conventions/treaty/148

Cummins, J. (2008). BICS and CALP: Empirical and theoretical status of the distinction. In B. Street \& N. Hornberger (Eds.), Encyclopedia of Language and Education (2nd ed., pp. 71-83). New York, NY: Springer.

Davies, A. (1996). Ironising the myth of linguicism. Journal of Multilingual and Multicultural Development, 17(6). Retrieved from http://ccat. sas.upenn.edu/ haroldfs/540/handouts/ideology/ linguism.html

Dearden, J. (2014). English as a medium of instruction - a growing global phenomenon: Interim report. Retrieved from http://www.britishcouncil.org/ sites/britishcouncil.uk2/files/english_as_a medium_of_instruction.pdf

Dearden, J., \& Akincioglu, M. (2016). EMI in Turkish universities: Collaborative planning and student voices. Retrieved from https://elt.oup.com/elt/ catalogue/pdf/emi_research_report.pdf

Diab, R. (2006). University students' beliefs about learning English and French in Lebanon. System, 34(1), 80-96.

Diab, R. (2009). Lebanese university students' perceptions of ethnic, national, and linguistic identity and their preferences for foreign language learning in Lebanon. The Linguistics Journal Special Edition: Language culture and identity in Asia,101120. Retrieved from https://www.linguisticsjournal.com

Docherty, C., Barakat, T., Kniveton, E., Mikati, L., \& Khalifa, H. (2017). Improving student learning through upskilling teachers: The case of Lebanon. Cambridge English language assessment research notes, 65, 75-88. Retrieved from http://www. cambridgeenglish.org/images/368332-researchnotes-65.pdf

Edge, J. (2003). Imperial troopers and servants of the Lord: A vision of TESOL for the 21st century. TESOL Quarterly, 37(4), 701-709.

Edge, J. (2006). (Ed.). (Re-)Locating TESOL in an Age of Empire. Basingstoke, UK: Palgrave.

EMI Oxford. (n.d.). Retrieved from http://www. education.ox.ac.uk/research/applied-linguistics/ emi/

Ennaji, M. (2005). Multilingualism, cultural identity and education in Morocco. New York, NY: Springer.

Esseili, F. (2011). English in Lebanon: Implications for national identity and language policy (Unpublished doctoral dissertation). Purdue University, Indianapolis, USA.
Esseili, F. (2014). English language teaching in Lebanese schools. In K. Bailey \& R. Damerow (Eds.), Teaching and learning English in the Arabic-speaking World (pp. 101-114). New York, NY: Routledge.

Ferguson, J., Collison, D., Power, D., \& Stevenson, L. (2009). Constructing meaning in the service of power: An analysis of the typical modes of ideology in accounting textbooks. Critical Perspectives on Accounting, 20(8), 896-909.

Findlow, S. (2006). Higher education and linguistic dualism in the Arab Gulf. British Journal of Sociology of Education, 27(1), 19-36. Retrieved from http:// www.jstor.org/stable/30036113

Fitzgibbon, L. (2013). Ideologies and power relations in a global commercial English language textbook used in South Korean universities: A critical image analysis and a critical discourse analysis (Unpublished doctoral thesis). University of Queensland, Brisbane, Australia. Retrieved from http://asianefl-journal.com

Galloway, N, \& Rose, H. (2015). Introducing Global Englishes. London, UK: Routledge.

Green, A., Wang, F., Cochrane, P., \& Paun, C. (2012). English spreads as teaching language in universities worldwide. University News, 229. Retrieved from http://www.universityworldnews.com/article. php?story $=20120621131543827$

Grin, F. (2004). On the costs of cultural diversity. In P. van Parijs (Ed.), Cultural diversity versus economic solidarity (pp. 189-202). Brussels, Belgium: De Boeck.

Hardt, M., \& Negri, A. (2001). Empire. Cambridge, MA: Harvard University Press.

Harvey, D. (2005). The new imperialism. Oxford, UK: Oxford University Press.

Hawkins, M.(Ed.). (2011). Social justice language teacher education. Clevedon, UK: Multilingual Matters.

Holborrow, M. (2007). Language, ideology and neoliberalism. Journal of Language and Politics, 6(1), 51-73.

Janks, H. (2000). Domination, access, diversity and design: A synthesis for critical literacy education. Educational Review, 52(2), 175-186.

Johnson, D. (2013). Language policy. Basingstoke, UK: Palgrave Macmillan.

Joseph, J. (2004). Language and identity. Basingstoke, UK: Palgrave Macmillan.

Kachru, B. B. (1997). World Englishes and Englishusing communities. Annual Review of Applied Linguistics, 17, 66-87. Retrieved from https://doi. org/10.1017/S0267190500003287

Kadi, S. (2016). French alive in Lebanon but not the in language' anymore. Retrieved from http://www. thearabweekly.com/Culture/7183/

Kaufman, A. (2014). Reviving Phoenicia: The search for identity in Lebanon. London, UK: I.B. Tauris and Co. 
Kirkpatrick, A. (2014). The language(s) of HE: EMI and/ or ELF and/or multilingualism. The Asian Journal of Applied Linguistics, 1(1), 4-15.

Kirkpatrick, A. (2016). EMI in HE in East and Southeast Asia. Paper presented at ETAL Seminar, University of Edinburgh, Edinburgh, UK.

Kirkpatrick, A. (2017). English language education policy in the Middle East and North Africa. New York, NY: Springer Publishing International.

Kumaravadivelu, B. (2006). Dangerous liaison: Globalization, empire and TESOL. In J. Edge (Ed.), (Re-) Locating TESOL in an Age of Empire (pp. 1-26). Basingstoke, UK: Palgrave.

Lin, A., \& Luke, A. (2006). Coloniality, postcoloniality, and TESOL. Can a spider weave its way out of the web that it is being woven into just as it weaves? Critical Inquiry in Language Studies, 3(2-3), 65-73. Retrieved from http://dx.doi.org/10.1080/15427587 .2006.9650844

Lindsey, U. (2015). How teaching in English divides the Arab world. The Chronicle of Higher Education, 61(38). Retrieved from https://www.chronicle.com/ article/How-Teaching-in-English/230705

Macaro, E. (2015). English medium instruction: Time to start asking some difficult questions. Modern English Teacher, 24(2), 4-7.

Marcus, E. (2016). The two language problem: Sélim Abou, Lebanon and the ethnolinguistic nation. British Journal of Middle Eastern Studies, 43(2), 219233. Retrieved from http://dx.doi.org/10.1080/1353 0194.2016.1138644

Marks, S. (2001). Big Brother is bleeping us - with the message that ideology doesn't matter. European Journal of International Law, 12, 109123. Retrieved from http://www.ejil.org/article. php?article $=498$ \&issue $=34$ \#download

Mehe. (2014). Reaching all children with education in Lebanon. Ministry of Education and Higher Education. Beirut, Lebanon: Lebanon.

Nader, S. (2014). Remittances key for Lebanon's economy. Al-Monitor: The pulse of the Middle East. Retrieved from http://www.almonitor.com/ pulse/originals/2014/11/lebanon-expatriateremittances-boost-economy.html

Orr, M. (2014). Ideology for second language teachers. Arab World English Journal, 5(4), 3-13. Retrieved from http://www.awej.org

Ostler, N. (2010). The Last lingua franca: English until the return of Babel. New York, NY: Walker.

Pathak, B. (2011). Teaching in Iraq: A job worth doing. Retrieved from https://www.facebook.com/ britishcouncil/posts/189497051090799

Phillipson, R. (1992). Linguistic imperialism. Oxford, UK: Oxford University Press.

Phillipson, R. (1997). Realities and myths of linguistic imperialism. Journal of Multilingual and Multicultural Development, 18(3), 238248. Retrieved June, 2017 from http://dx.doi. org/10.1080/01434639708666317

Phillipson, R. (2008). The linguistic imperialism of neoliberal empire. Critical Inquiry in Language Studies, 5(1), 1-43. Retrieved from http://dx.doi. org/10.1080/15427580701696886

Phillipson, R. (2009). Linguistic imperialism continued. London, UK: Routledge.

Phillipson, R. (2017). Myths and realities of 'global' English. Language Policy, 16(3), 313-331.

Piller, I. (2016). Linguistic diversity and social justice: An introduction to applied sociolinguistics. Oxford, UK: Oxford University Press.

Raddawi, R. \& Meslem, D. (2015). Loss of Arabic in the UAE: Is bilingual education the solution? International Journal of Bilingual \& Multilingual Teachers of English, 3(2), 85-94.

Robson, C. (2011). Real world research. Chichester, UK: Wiley.

Said, E. (1993). Culture and imperialism. New York, NY: Vintage.

Salameh, F. (2010). Language, memory and identity in the Middle East: The case for Lebanon. Lanham, MD: Lexington Books.

Salamey, I. (2014). The government and politics of Lebanon. New York, NY: Routledge.

Salloukh, B., Barakat, R., Al-Habal, J., Khattab, L., \& Mikaelian, S. (2015). The politics of sectarianism in postwar Lebanon. London, UK: Pluto.

Shaaban, K. (2005). English language teaching in Lebanon: Challenges for the future. In G. Braine (Ed.), Teaching English to the world: History, curriculum and practice (pp. 103-113). Mahwah, NJ: Lawrence Erlbaum Associates Incorporated.

Shaaban, K. (2013). Disparity between ideals and reality in curriculum construction: The case of the Lebanese English language curriculum. Creative Education, 4(12B), 28-34. Retrieved from http://file. scirp.org/Html/41429.html

Shaheen, K. (2016). Nobody wants to stay in Lebanon. It's a miserable life. Retrieved from https://www. theguardian.com/world/2016/apr/06/lebaneserefugees-nobody-wants-stay-lebanon-miserablelife

Shawish, H. (2010). Campaign to save the Arabic language in Lebanon. Retrieved from http://www. bbc.co.uk/news/10316914

Shohamy, E. (2013). A critical perspective on the use of English as a medium of instruction at universities. In A. Doiz, D. Lasagabaster \& J. M. Sierra (Eds.), English-medium instruction at universities: Global challenges (pp. 196-210). Clevedon, UK: Channel View.

Slee, R. (2001). Social justice and the changing directions in educational research: The case 
of inclusive education. International Journal of Inclusive Education, 5(2), 167-177. Retrieved from http://dx.doi.org/10.1080/13603110010035832.

Solloway, A. (2017). English in the United Arab Emirates: Innocuous lingua franca or insidious cultural trojan horse? In L. Buckingham (Ed.), Language, Identity and Education on the Arabian Peninsula: Bilingual Policies in a Multilingual Context (pp. 176-196). Bristol, UK: Multilingual Matters.

Suleiman, Y. (2006). Charting the nation: Arabic and the politics of identity. Annual Review of Applied Linguistics, 26, 125-148.

Thompson, J. (1990). Ideology and modern culture: Critical social theory in the era of mass communication. Cambridge, UK: Polity Press.

Tollefson, J. (2013). Language policy in a time of crisis and transformation. In J. Tollefson (Ed.), Language policies in education: Critical issues (pp. 11-34). New York, NY: Routledge.

Traboulsi, F. (1999). SilatBilaWasel: Micel Chiha wa al idologiya al Lubnaniya [Michel Chiha and the Lebanese ideology]. Beirut, Lebanon: Dar Al Saqi.

Traboulsi, F. (2007). A history of modern Lebanon. London, UK: Pluto.

UNESCO. (n.d.). Retrieved from http://www.unesco. org/new/en/education/themes/strengtheningeducation-systems/languages-in-education/ international-mother-langage-day/articlesimld-2012/

UNICEF. (2012). Education and rapid needs assessment for displaced Syrian children in Schools, Community and Safe Spaces. Retrieved from https://data.unhcr. org/syrianrefugees/download.php?id $=535$

Vu, N. T. T., \& Burns, A. (2014). English as a medium of instruction: Challenges for Vietnamese tertiary lecturers. The Journal of Asia TEFL, 11(3), 1-31.

Warschauer, M. (2003). The allures and illusions of modernity: Technology and educational reform in Egypt. Educational policy archives. Retrieved from http://epaa.asu.edu/ojs/article/view/266/392

Wiley, T. (2013). A brief history and assessment of language rights in the United States. In J. Tollefson (Ed.), Language policies in education: Critical issues (pp. 61-90). New York, NY: Routledge.

Wilkinson, R. (2012). English-medium instruction at a Dutch university: Challenges and pitfalls. In A. Doiz, D. Lasagabaster \& J. M. Sierra (Eds.), Englishmedium instruction at universities: Global challenges (pp. 1-24). Clevedon, UK: Channel View.

Wrigley, T., \& Smyth, J. (2013). Living on the edge: Rethinking poverty, class and schooling. New York, NY: Peter Lang Publishing.

Wright, S. (2007). The right to speak one's own language: Reflections on theory and practice. Language Policy, 6(2), 203-224. Retrieved from http://dx.doi.org/10.1007/s10993-007-9050-y

Yaacoub, N., \& Badre, N. (2012). Education in Lebanon. Statistics in Focus, 3. Beirut, Lebanon: Central administration for statistics. Retrieved from http:// civilsociety-centre.org/resource/statistics-focuseducation-lebanon

Zakharia, Z. (2009). Positioning Arabic in schools: Language policy, national identity, and development in contemporary Lebanon. In F. Vavrus \& L. Bartlett (Eds.), Critical approaches to comparative education: Vertical case studies from Africa, Europe, the Middle East, and the Americas (pp. 215-231). New York, NY: Palgrave Macmillan.

Zakharia, Z. (2010). Language-in-education policies in contemporary Lebanon: Youth perspectives. In O. Abi-Mershed (Ed.), Trajectories of education in the Arab world: Legacies and challenges (pp. 56-184). New York, NY: Routledge. 